\title{
E-SCIENCE: THE FOURTH PARADIGM IN SCIENCE AND RESEARCH DATA MANAGEMENT
}

\author{
Ekawati Marlina \\ Indonesian Institute of Sciences
}

Correspondence: ekawati.marlina@lipi.go.id

\begin{abstract}
Research is a process of systematic problem solving using scientific methods. One of the main outputs in research is data. The development of new analytical methods in research led to the emergence of the e-science era. In that era, there was a change in the type, volume, and diversity of research data. With the advent of the e-science era, libraries in universities and research institutes in addition to managing publications also manage research data. By using the narrative review method, an exploration is carried out to identify the paradigms in science and their relation to research data management. Identification is done by using the perspective of paradigm and epistemology. From the results of exploration, it is known that e-science is the fourth paradigm in science. The paradigm shift is due to the development of new analytical methods in scientific research. The shift in the research paradigm has changed the data life cycle. In the new life cycle, data becomes an important part of each stage of research activities. Research data management is important so that data can be accessed for a long period of time, shared and reused. Data sharing is a new stage that has emerged in the data lifecycle in the e-science era. From an epistemological perspective, reproduction and verification are problematic issues in data sharing.
\end{abstract}

\begin{abstract}
ABSTRAK
Penelitian merupakan proses mencari pemecahan suatu permasalahan secara sistematis dengan menggunakan metode ilmiah. Salah satu output utama dalam penelitian yaitu data. Pengembangan metode analitis baru dalam penelitian menyebabkan munculnya era e-science. Dalam era tersebut terjadi perubahan pada jenis, volume, dan keragaman data penelitian. Dengan munculnya era e-sains, perpustakaan di universitas dan lembaga penelitian selain mengelola publikasi juga mengelola data penelitian. Dengan menggunakan metode narrative review, dilakukan eksplorasi untuk mengidentifikasi paradigma dalam ilmu pengetahuan dan keterkaitannya dengan manajemen data penelitian. Identifikasi dilakukan dengan menggunakan perspektif paradigma dan epistemologi. Dari hasil eksplorasi diketahui bahwa e-science merupakan paradigma ke empat dalam ilmu pengetahuan. Pergeseran paradigma disebabkan karena adanya pengembangan metode analitis baru dalam penelitian ilmiah. Pergeseran paradigma penelitian telah merubah siklus hidup data. Dalam siklus hidup yang baru, data menjadi bagian penting dalam setiap tahap kegiatan penelitian. Manajemen data penelitian menjadi penting dilakukan agar data dapat diakses dalam jangka waktu yang lama, dibagi, dan digunakan kembali. Berbagi data merupakan tahap baru yang muncul pada siklus hidup data dalam era e-science. Dari perspektif epistemologi, reproduksi dan verifikasi merupakan masalah problematik dalam berbagi data.
\end{abstract}

Keywords: E-science; Research data management; Science paradigm; data lifecycle

\section{INTRODUCTION}

Research data management practices have been carried out in higher education institutions and research institutions. United States, United Kingdom, Australia, Netherland, and China have a number of higher education institute which implemented research data services ( $\mathrm{Si}$ et al. 2015). The changes in funding agencies' policy and e-science are the main factors that lead research data management (RDM) toward getting attention from various parties, especially research institutions and higher education institutions (Cox et al. 2017; Henderson and Knott 2015). Funding agencies require a research data management plan as part of the proposal. The existence of this policy is an effort from funding agencies to implement good practices in research. According to Jim Gray, the changes of research paradigm has led us to be in the era of e-science or data-driven science (Hey, Tansley, and Tolle 2009). Transformation of research methods has a great effect on the 
research data output. Data generated from the research process in digital form has increasingly large volumes with high variety.

Management of research data enables verification of reliable results and sharing data with the wider community. The library is a sub-organization in higher education that is responsible for managing the research data. Managing data is the role of libraries that emerged in the era of e science (Bryan Heidorn 2011). Martin, Cadiou, and Jannès-Ober (2017) state that to support research in the e-science era, the French National Research Institute of Science and Technology for Environmental and Agriculture develops research data management services. The service involves all professionals, including librarians, and researchers. To implement RDM service, the librarian should have broadened the horizon and understanding of e-science. Hence, this article explored what are e-science and its effects on RDM. Philosophical perspectives, especially paradigms and epistemologies, are used in this exploration.

\section{METHOD}

The method used in this paper is narrative review, conducted by searching for paper related to e-science and RDM. This method is used to synthesize the published literature and describe its current state of particular topic (Ferrari 2015). Content analysis is carried out to select the appropriate literature. The literature analysis technique uses thematic analysis. The technical analysis is appropriate to be used for research aimed at exploring what actually happens in a phenomenon (Heriyanto 2018). Selected literature is grouped based on certain themes that have been determined. The steps of the research are shown in Figure 1.

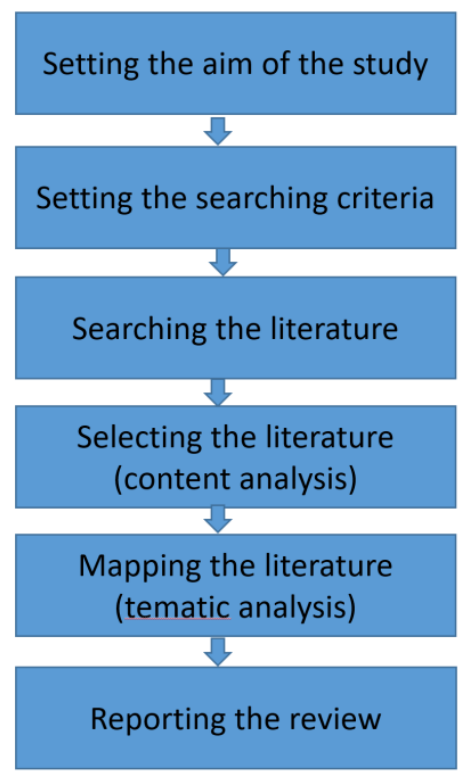

Figure 1. Research process

\section{RESULTS AND DISCUSSION}

The discussion is divided into three themes, namely e-science and the paradigm of science; e-science and research data management; and research data management and epistemology.

\section{a. $\quad$ E-science and the paradigm of science}

Paradigm is a person's perspective on a fundamental issue to understand basic knowledge and belief that guides a person to act in daily life (Diamastuti 2012). According to Kuhn, 
paradigms are accepted ways to study and synthesize general to primary knowledge for most researchers in a discipline at a certain time. Kuhn argues that regularly, new ways of thinking will emerge that challenge accepted theories and approaches. The paradigm shift occurs because science cannot explain certain phenomena or answer critical questions, so it requires the preparation of new ideas.

According to Jim Gray (Kitchin 2014), we are currently in the era of e-science or the fourth paradigm. Jim Gray divided the evolution of science into four paradigms (Table 1). Kuhn and Jim Gray have different views about the causes of paradigm shifts. According to Gray, the transition of knowledge is due to the development of the new analytical method in scientific research and not because of opposition to theory.

From Table 1, it appears that experimental science is the first paradigm. Theoretical science, with Kepler's law, Newton's law of motion, and Maxwell's equations are in the second phase. In many problems, the use of the theoretical model becomes very complicated; then a simulation emerges as a new method to simplify the problems that arise. Simulation is the third paradigm, which is also known as computational science. The simulation phase takes place in most of the last half millennium. The last paradigm or the fourth paradigm is data-intensive science or escience. The differences between data-intensive sciences with computational science are in terms of techniques and technology that are used for scientific exploration.

E-science is where "IT meets with scientists". Researchers use a variety of different methods to collect or produce data. Researchers today do not see directly through a telescope. Instead, they look through large scale, complex instruments that convey data to the data center, and they only see the information on the computer. It can be concluded that the development of computer science primarily influences e-science. The use of high-level computing tools is carried out in various discipline, including in social sciences. Obstacles in e-science's effectiveness are not technical but rather social problems (Schroeder and Fry 2007). Therefore in e-science, a collaboration between dicipline is needed. In social science, there are various approaches to forming new forms of research, governance, communication, and collaboration, such as sociology of science, economic innovation, and research policy.

Table 1. Four paradigms of science.

\begin{tabular}{|c|c|c|}
\hline Paradigm & Nature & Form \\
\hline First & Experimental science & Empiricism; describing natural phenomena \\
\hline Second & Theoritical science & Modelling and generalization \\
\hline Third & Computational science & Simulation of complex phenomena \\
\hline Fourth & Exploratory science & $\begin{array}{c}\text { Data-intensive; statistical exploration and } \\
\text { data mining }\end{array}$ \\
\hline
\end{tabular}

(Source: Kitchin 2014)

\section{b. E-science and Reaserch data management}

RDM is a series of activities carried out before, during, and after the research activities take place. RDM allows data to be preserved (accessed for a long time), shared, and reused. Data management is carried out at all stages in the entire lifecycle.

To find out the effect of e-science in RDM, the role of data in research activities is seen. The data lifecycle helps identify the role of data in different parts of the research activity. Along with changes in the research paradigm, the role of data in research has changed. There are two data lifecycles, namely the data lifecycle of old and new ones. Identification of these changes can be explained in the old data life cycle (Figure 2) and new (Figure 3) (Briney 2015). 


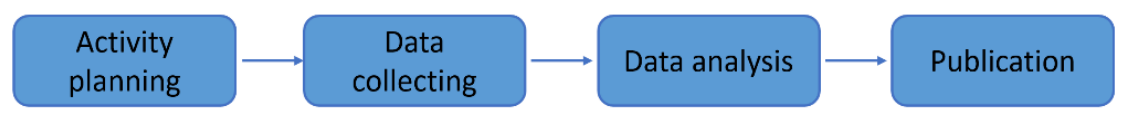

Figure 2. Old data lifecycle

Source: (Briney 2015)

In Figure 2, it appears that there are four stages in the research activity. The data lifecycle starts from the planning of activities and ends with publication, which is generally in the form of scientific articles published in journals or proceedings. In planning and publication activities, it appears that data has no role. Data seems to only play a role in the data collection and analysis stage. If examined, actually researchers have designed the form of data that will be collected from the activity planning stages. In addition, the researcher has also planned the representation of data that will be displayed in the publication. Although it only has a small role in the activity planning and publication stages, data is important at all stages of the research process.

Synthesis results from data are displayed in articles published in journals or proceedings. After publication, data is left or ignored until it is finally inaccessible. It can be concluded that data is a by-product of research and not an important product of research. The main products are articles. The system went well for hundreds of years, but with a paradigm shift in research, where generally research data in the form of digital data made us able to do more with the data. Data is not only lost at the end of the activity but is used for advanced analysis. Therefore, a new data life cycle appears.

In the life cycle of new data (Figure 3), the stages of the research process add data sharing, data preservation, and data reuse. In this life cycle, research data has a greater importance than the old life cycle. Data is a product of actual research, not just by-products. Data from previous research activities can be input to new activities and cause the cycle to start from the beginning again. Data is not lost at the end of the activity but is preserved and reused. With the sharing of data, allowing data generated from previous research activities to be input for other activities.

At the stage of activity planning and data management, researchers formulate a strategy of how the research data held will be managed, make a data management plan, and be responsive to data policies that apply to the research activities carried out. This is an addition, as before activities only involve planning in general and reading literature.

The next stage of research is data collection. In terms of data management, at this stage documentation and organization of data is carried out. Documentation includes everything from the use of laboratory records, metadata, and protocols and other important documentation formats such as how to read data and data dictionaries. Data organization strategies include organizing files, filing names, and using databases. 


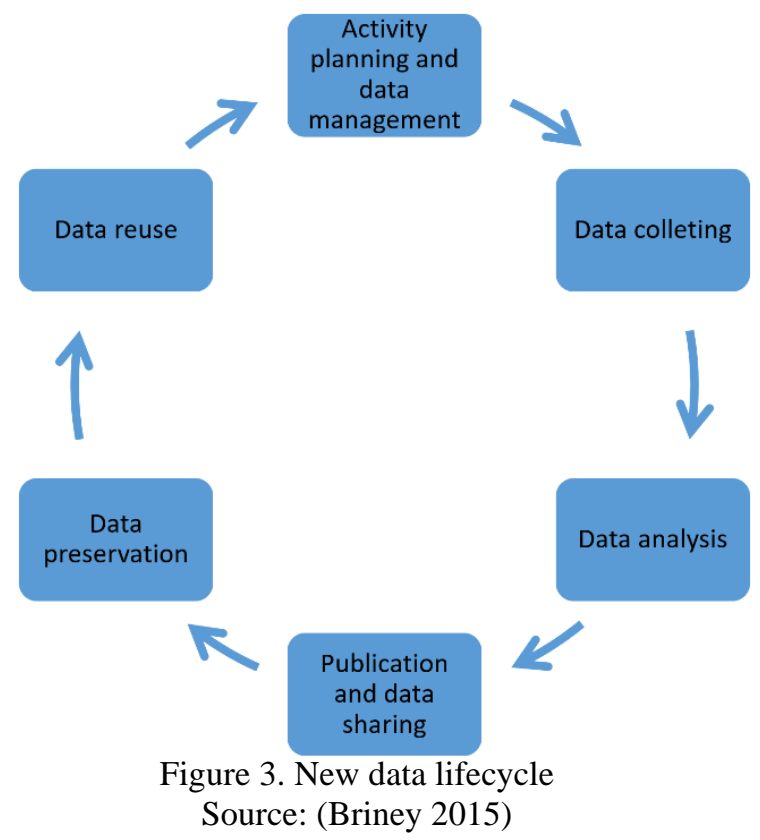

Data management only plays a small role during the data analysis phase. At this stage, the following needs to be considered: namely, knowing the difference between managing raw data and analyzed data and performing data quality control. The data management strategy is also expanded to manage the research code.

At the stage of data collection and analysis, data storage and backup is important. Then, at the stage of data sharing and data preservation, it requires long-term storage. Other things that need to be considered in research data management include what data needs to be maintained and how to maintain it, how to prepare data for long-term storage, and how to preserve data in a data repository. If the data is sensitive, such as personal data information, it needs to be managed more carefully. In data management, types of data need to be considered as some require extra security, maintenance of data security, and anonymization of data.

\section{c. Reaserch data management and epistemology}

In the e-science era, research data comes from data captured from instruments or generated from a simulator, processed by the software, information/knowledge stored on computers, and analyzed using data management or statistics. Data-intensive science consists of three basic activities, namely capturing, curating, and analyzing (Hey, Tansley, and Tolle 2009). Data comes from many scale and form of research activities from any discipline - the big size of research such as large international scale experiments that are cross-laboratory, cross-discipline, and crossgeographic. Many problems arise from large-scale research. For example, the research activities carried out by CERN are on an international scale, involving many scientists from various countries. The research produces data up to several petabytes per day, but their velocity is limited to the range that is easily managed.

The first activity in data-intensive science is capturing data using tools. The tools used make it possible to capture data on a mega or milimeter scale. After data is captured, the data needs to be curated before analysis. Curation is an activity ranging from finding the right data structure until mapping data into various storages. Data curation also includes the determination of schemes and metadata for long-term availability and integration between instruments, eksperiments, and laboratories. Not all data must be available in the long term period. We must 
consider how long the data should be available and what kind of metadata should be captured. The second activity is data analysis. These activities include database usage, analysis and modeling, and data visualization. Data analysis is continued by publishing the result in a journal or other publication media. Several columns in the journal are not really enough to represent a large number of data. Because of that, some journal publisher requires the publication of paper accompanied by the publication of research data.

By using new analytical methods, researchers produce data in very large amounts which can be said to be a flood of data. Reuse of data can be done if data is shared by the owner. The aim of data sharing is to re-produce or verify research, making publicly funded research data available to the public, making it possible for others to conduct new research question, and improving the innovation (Borgman 2012). From an epistemological, re-producing or verifying are problematic issues among others in data sharing. Re-produce research needs a deep understanding of the epistemology of the research. Data reproduction actors must really know the meaning of data and sometimes this cannot easily be found.

Jones et al. (2018) states that one of the challenges in sharing qualitative data is epistemology. Various methodologies and approaches in the collection and analysis of qualitative data derived from different epistemologies. Epistemogy or known as "knowledge theory" is related to the scope and boundaries of what and how we know something. Epistemology investigates the origin, structure, method and validity of justifications for classifying something as knowledge. Epistemology begins with steps: problem formulation, compilation of mindset, hypothesis formulation, and conclusion drawing (Bahrum 2013). In qualitative research, the epistemological approach greatly influences the possibility that a researcher will be compelled share his data or reuse it for synthesis purposes (Jones et al. 2018). Epistemology also has an impact on the form, content, and range of data shared. The practice of sharing data is still done very little. It is common in conducting research in the fields of astronomy and genomics (Borgman 2012). This is because in these fields there are no epistemological problems in sharing data. Data is seen to be a separate representation and defined objectively.

\section{CONCLUSION}

E-science or the fourth paradigm in science arises not because of opposition to theory but because of the development of new analytical methods. E-science is where "IT meets with scientists". In the e-science era, researchers used a variety of different methods to collect or produce data.

Data is an important part in each stage of research activities. In the new data lifecycle, the stages of the research process are activity planning, data collection, data analysis, data publication and sharing, data preservation, and data reuse. Research data management is carried out at all stages of the research activity.

The emerging step in data lifecycle is data sharing and data reuse. From an epistemological, reproductive, and verification perspective, there is a problematic issue in sharing data.

\section{BIBLIOGRAPHY}

Bahrum. 2013. 'Ontologi, Epistemologi, Dan Aksiologi'. Jurnal Sulesana 8 (2): 35-45.

Borgman, C L. 2012. 'The Conundrum of Sharing Research Data'. Journal of the American Society for Information Science and Technology 63 (6): 1059-78. https://doi.org/10.1002/asi.

Briney, Kristin. 2015. Data Management for Researchers: Organize, Maintain and Share Your 
Data for Research Success. Exeter: Pelagic Publishing, UK.

Bryan Heidorn, P. 2011. 'The Emerging Role of Libraries in Data Curation and E-Science'. Journal of Library Administration 51 (7-8): 662-72.

https://doi.org/10.1080/01930826.2011.601269.

Cox, A M, M A Kennan, L Lyon, and S Pinfield. 2017. 'Developments in Research Data Management in Academic Libraries: Towards an Understanding of Research Data Service Maturity'. Journal of the Association for Information Science and Technology 68 (9): 2182 2200. https://doi.org/10.1002/asi.23781.

Diamastuti, Erlina. 2012. 'Paradigma Ilmu Pengetahuan Sebuah Telaah Kritis'. Jurnal Akuntansi Universitas Jember 10 (1): 61-74. https://doi.org/https://doi.org/10.19184/jauj.v10i1.1246.

Ferrari, Rossella. 2015. 'Writing Narrative Style Literature Reviews Correspondence To'. Medical Writing 24 (4): 230-35. https://doi.org/10.1179/2047480615Z.000000000329.

Henderson, Margaret E., and Teresa L. Knott. 2015. 'Starting a Research Data Management Program Based in a University Library'. Medical Reference Services Quarterly 34 (1): 47 59. https://doi.org/10.1080/02763869.2015.986783.

Heriyanto, Heriyanto. 2018. 'Thematic Analysis Sebagai Metode Menganalisa Data Untuk Penelitian Kualitatif'. Anuva 2 (3): 317. https://doi.org/10.14710/anuva.2.3.317-324.

Hey, Tony, Stewart Tansley, and Kristin Tolle. 2009. The Fourth Paradigm: Data-Intensive Scientific Discovery. United States of America. https://www.microsoft.com/enus/research/wp-content/uploads/2009/10/Fourth_Paradigm.pdf.

Jones, Kristal, Steven M Alexander, Nathan Bennett, L. Bishop, A. Budden, M. Cox, M. Crosas, et al. 2018. Qualitative Data Sharing and Re-Use for Socio-Environmental Systems Research: A Synthesis of Opportunities, Challenges, Resources and Approaches. National Science Foundation. https://doi.org/10.13016/M2WH2DG59.Permanent.

Kitchin, Rob. 2014. 'Big Data, New Epistemologies and Paradigm Shifts'. Big Data \& Society 1 (1): 205395171452848. https://doi.org/10.1177/2053951714528481.

Martin, Caroline, Colette Cadiou, and Emmanuelle Jannès-Ober. 2017. 'Data Management: New Tools, New Organization, and New Skills in a French Research Institute'. LIBER Quarterly 27 (1): 73-88. https://doi.org/10.18352/lq.10196.

Schroeder, Ralph, and Jenny Fry. 2007. 'Social Science Approaches to E-Science: Framing an Agenda'. Journal of Computer-Mediated Communication 12 (2): 229-48. https://doi.org/10.1111/j.1083-6101.2007.00338.x.

Si, Li, Wenming Xing, Xiaozhe Zhuang, Xiaoqin Hua, and Limei Zhou. 2015. 'Investigation and Analysis of Research Data Services in University Libraries'. Electronic Library 33 (3): 417 49. https://doi.org/10.1108/EL-07-2013-0130. 